\title{
The Interactive Relationship between Credit Growth and Operational Self-Sustainability of People's Credit Funds in Mekong Delta Region of Vietnam
}

\author{
Duong Van HA ${ }^{1}$
}

Received: July 9, 2019 Revised: July 16, 2019 Accepted: July 17, 2019

\begin{abstract}
The purpose of this study is to discover the interaction between credit growth and operational self-sustainability and to examine factors that affect credit growth and operational self-sustainability of people's credit funds (PCFs). Credit growth and operational self-sustainability are factors affecting the operations and the goals of people's credit funds (PCFs) in the Mekong Delta region of Vietnam. After regression analysis on a set of panel data from 2013 to 2018 of 24 PCFs, it appears that deposit growth and loan-to-deposit ratio have positive relationships with credit growth, while capital adequacy ratio and operational self-sustainability have negative relationships with credit growth of PCFs; capital adequacy ratio, deposit growth and income have positive relationships with operational self-sustainability, while credit growth and non-performing loan ratio have negative relationships with the operational self-sustainability of PCFs. At the same time, credit growth and operational self-sustainability have a relationship to interact with each other in a contrary trend. The results of this research are accurate according to the characteristics and development history of PCFs in the Mekong Delta region of Vietnam from 2013-2018. This study helps researchers and managers to understand the key determinants for better management of PCFs.
\end{abstract}

Keywords: Credit, Operational Self-Sustainability, People's Credit Fund, Credit Growth, Vietnam

JEL Classification Code: G19, G21, G29.

\section{Introduction}

People's credit fund is one of the institutions that provide microfinance services. The operation of PCFs in Vietnam has made an important contribution to expanding the scale of the financial service provision, especially providing financial services for the poor, low-income people and contributing to ensuring social security. Increasing the ability to provide financial services is one of the important orientations that are targeted by many PCFs. With this orientation, PCFs in Vietnam expand the scale of the

1 First Author and Corresponding Author. PhD. Postgraduate Training Institute, Hong Bang International University, Ho Chi Minh City, Vietnam [Postal Address: No 78/35 Ba Van, Ward 14, Tan Binh District, Ho Chi Minh City, 700000 Vietnam].

Email: dhv05@yahoo.com

$\odot$ Copyright: Korean Distribution Science Association (KODISA)

This is an Open Access article distributed under the terms of the Creative Commons Attribution NonCommercial License (https://creativecommons.org/licenses/by-nc/4.0/) which permits unrestricted noncommercial use, distribution, and reproduction in any medium, provided the original work is properly cited. service provision and need to ensure the balance of the social, income and operational self-sustaining goals. However, credit growth is very low and tends to decrease; besides, the operational self-sustainability of many PCFs in the Mekong Delta region of Vietnam has fluctuated over the years, affecting the ability to expand the scale of the financial service provision. The study of the interaction between credit growth and operational self-sustainability of PCFs is one of the urgent issues in order to find out the relationship, the interaction trend to promote credit growth and improve the operational self-sustainability of PCFs in the Mekong Delta region of Vietnam.

\section{Literature Review}

In Vietnam, PCF is a credit institution established voluntarily by legal entities, individuals and households as a cooperative to conduct some banking operations under the Law on Credit Institutions and the Law on Cooperatives for 
the main purpose of mutual assistance in production and business development and life (The National Assembly, 2010).

Therefore, PCF is a legal entity that provides financial services with the main purpose of mutual assistance in production and business development and life. PCF plays an important role in the economy and social development, contributes to strengthening and expanding the formal financial systems. At the same time, PCF attracts capital from savings mobilization to serve the needs of investment, production, and exchange of goods, thereby contributing to poverty reduction and income improvement for members and customers. To play this important role, one of the requirements for PCFs is ensuring operational selfsustainability and credit growth.

\subsection{Factors Affecting Credit Growth of PCFs}

Credit growth has always been the top concern of PCFs. Because reasonable and high quality credit growth will create stable and safe income for PCFs. Credit growth is an increase in credit supply of PCFs, which is a operation associated with the development process of PCFs and is influenced by many factors, including:

Firstly, capital adequacy ratio: Capital adequacy refers to the level of capital in an organization that is available to cover its risk. All financial institutions are required to have a minimum amount of capital relative to the value of their asset. This means that in the event of asset loss, the organization would have sufficient funds of its own to cover the loss (Ledgerwood, 1999). According to Berrospide and Edge (2010), there are effects of capital on loan growth and the capital changes on loan growth of credit institutions. The effects of recapitalization on loan growth depend on the starting capital positions of the institutions and the size of capital injections (Catalán, Hoffmaister, \& Harun, 2017). When capital requirements of Basel II are between $1-2 \%$, the credit institutions lend more, which allows them to accumulate retained earnings through increased revenues. The quantitative impact of an increase in required capital is a sizable increase in lending (Phi, Hoang, TaghizadehHesary, \& Yoshino, 2019).

H1.1: There is a significant relationship between capital adequacy ratio and credit growth of PCFs.

Secondly, the deposit growth: Deposit growth, which is defined as the change of total deposits scaled by total assets in a year, is expected to have a positive relationship with loan growth. Credit institutions which have more funding availability will be able to perform their financial intermediation function better and should have stronger lending growth. Credit institutions which have higher deposit growth tended to expand credit more rapidly (Barajas, Chami, Espinoza, \& Hesse, 2010). Besides, the deposit expansion contributes positively to credit growth of credit institutions (Tan, 2012).

H1.2: There is a significant relationship between mobilization deposit growth and credit growth of PCFs.

Thirdly, equity growth: There is the long-run relationship between equity capital and demand for bank credit (Oliver, Ruano, \& Fumás, 2012). Recently, there has been new interests in the effects of equity capital on bank credit, studies have provided estimations of the effect of a marginal change in equity ratio on the growth rate of loans (Alnahedh \& Bhagat, 2017). The results indicate that the increase in equity ratio is associated with the increase in new loan lending. On the one hand, credit institutions with low capital cannot generate new loans instantly and have to compete for deposits or raise equity capital first before being able to generate new loans. On the other hand, well-capitalized credit institutions, who have equity capital exceeds capital requirements, possess a greater capacity to generate loans given their excessive equity capital (Alnahedh \& Bhagat, 2017).

H1.3: There is a significant relationship between equity growth and credit growth of PCFs.

Fourthly, loan-to-deposit ratio: Loan-to-deposit ratio is used as a proxy for relative loan activity (Barkley, Mellon, \& Potts, 1984). Loan-to-deposit ratio is a key indicator to be monitored to take the gauge of credit institutions' structural liquidity positions. It is a ratio showing how much credit of these institutions is funded by key stable funding resources, namely deposits. Loan-to-deposit ratio of large credit institutions reached high ratio as their lending expanded rapidly (DiSalvo \& Johnston, 2017).

H1.4: There is a significant relationship between loan-todeposit ratio and credit growth of PCFs.

Fifthly, non-performing loan ratio: The ratio of nonperforming loans has a negative and significant impact on credit operations (Rabab'ah, 2015). Besides, there is a reverse relationship between the rate of non-performing loans and credit growth rate for all the observed countries (Alihodžić \& Ekşi, 2018).

H1.5: There is a significant relationship between nonperforming loan ratio and credit growth of PCFs. 
Sixthly, operational self-sustainability: The operational self-sustainability has a relation to credit growth of the credit institutions. Measuring operational self-sustainability creates an incentive to increase loan volume (Lyons, 2012).

H1.6: There is a significant relationship between operational self-sustainability and credit growth of PCFs

Seventh, economic growth: Economic growth represents the gross domestic product (GDP) annual growth (Growe, DeBruine, Lee, \& Maldonado, 2014), the economic growth affects credit growth (Bakker \& Gulde, 2010). The higher economic growth is, the higher credit growth is (Barajas, Chami, Espinoza, \& Hesse, 2010), and the stronger economic growth leads to higher credit growth (Guo \& Stepanyan, 2011). However, some studies have shown that credit growth is significantly related to economic growth, but economic growth has a negative influence (Wachukwu, Onyema, \& Amadi, 2018).

H1.7: There is a significant relationship between economic growth and credit growth of PCFs.

Eighth, inflation: Inflation is determined by the changing of consumer price index annually (Growe, DeBruine, Lee, \& Maldonado, 2014), credit grows when there is high inflation (Bakker \& Gulde, 2010) while high inflation increases nominal credit (Guo \& Stepanyan, 2011).

H2.8: There is a significant relationship between inflation and credit growth of PCFs.

\subsection{Factors Affecting Operational Self- sustainability of PCFs}

Sustainability is the goal of many sectors and fields in countries around the world, each country will rely on economic and social characteristics to plan the most suitable strategy for sustainable development. Sustainability generally means the ability of an ongoing program to perform activities and services in pursuit of the planned objectives. For an ideal microfinance institution, this means the ability to continuously operate. Achieving sustainability is a guarantee for microfinance institutions to be safe in their activities in order to consolidate their future (Delija \& Qirici, 2015). A microfinance institution will have operational selfsustainability if the revenue it generates from the operations covers its operating expenses, financing costs and loan loss provisions (Ledgerwood, 1999). Sustainability can be defined as the ability of the organization to meet the operating cost and build enough reserves for recapitalization
(UNESCAP, 2006). Therefore, operational self-sustainability in PCFs refers to the ability of institutions to cover their operating expenses, financing costs and loan loss provisions from their operating revenues.

The operational self-sustainability is a tangible parameter that is measured continuously to monitor the level of income to cover all costs to ensure that PCFs will develop in longterm. The operational self-sustainability is associated with all PCFs activities and is influenced by many factors, including:

Firstly, capital adequacy ratio: Capital adequacy ratio reflects the structure and sufficiency of the capital of PCFs. Capital adequacy means that there is a sufficient level of capital required to absorb potential losses and provide financial sustainability. Sufficient capital is one of the key factors affecting the healthiness and sustainability of microfinance institutions since sufficient capital encourages lenders and depositors to have confidence in the microfinance institutions relative (Ledgerwood, 1999).

H2.1: There is a significant relationship between capital adequacy ratio and operational self-sustainability of PCFs.

Secondly, credit growth: The sustainability of microfinance goes along with commercial viability and institutional growth (Weber, 2013). The financial sustainability of microfinance institutions is positively and significantly driven by loan intensity and size (Tehulu, 2013). There is a significant relationship between loan-size growth and sustainability (MkNelly \& Stack, 1998) and loan growth is important to financial sustainability and has positive impacts (Painter \& MkNelly, 1999).

H2.2: There is a significant relationship between credit growth and operational self-sustainability of PCFs.

Thirdly, deposit growth: Institutional sustainability was the key to the successful provision of financial services to the poor and financial self-sufficiency is a necessary condition for institutional sustainability (Brau \& Woller, 2004). Thus, connecting microfinance and the mainstream financial sector is considered to be an effective way to enhance the outreach and sustainability of microfinance through such financial instruments as mobilization of funds. A sustainable microfinance institution offers services to its clients on a continuous basis and is able to meet the needs of the members through resources raised from operations and external sources (UNESCAP, 2006). The objectives of mobilizing deposits are twofold: (i) to provide relatively secure deposit services that meet the demand of large numbers of poor people on an ongoing basis; and (ii) to 
improve the sustainability of institutions that provide credit to the poor by developing a relatively stable means to finance their portfolios (CGAP, 2005).

H2.3: There is a significant relationship between deposit growth and operational self-sustainability of PCFs.

Fourthly, equity growth: Sustainability means full cost recovery or profit-making to build microfinance institutions that can operate in the future without relying on government subsidies or donor funds (Conning, 1999). A sustainable microfinance institution offers services to their clients on a continuous basis and is able to meet the needs of members through resources raised from operations (UNESCAP, 2006). The financial sustainability of microfinance goes along with commercial viability and institutional growth in order to avoid relying on donors and to attract investors who want to support the growth of microfinance (Weber, 2013). The more equity is used to provide microfinance services compared to other sources of finance, the more improvements in the sustainability of microfinance institutions are (Harelimana, 2017).

H2.4: There is a significant relationship between equity growth and operational self-sustainability of PCFs.

Fifthly, income: Microfinance institutions achieve selfsustainability when their income exceeds the costs (Yaron, 1992). An analysis of profit-motivated microfinance institutions revealed that profit-motivated microfinance institutions have a higher rate of sustainability compared to non-profit microfinance institutions (Amit \& Kedar, 2014). People's credit fund is one of the institutions that provide microfinance services that are profit-motivated; thus, the income will affect the operational self-sustainability of PCFs.

H2.5: There is a significant relationship between the income and operational self-sustainability of PCFs.

Sixth, non-performing loan ratio: Loan repayment could be another indicator for financial sustainability (Khandker, Khalily, \& Khan, 1995), financial sustainability requires financial institutions to maintain good financial status, the financial un-sustainability in financial institutions arises due to low repayment rate (Meyer, 2002). Financial sustainability is the key condition for operational self-sustainability; therefore, non-performing loan ratio affecting financial sustainability will affect the operational self-sustainability of PCFs.
H2.6: There is a significant relationship between nonperforming loan ratio and operational selfsustainability of PCFs.

\section{Research Methodology}

The study uses both primary and secondary data. Secondary sources of data are gathered from international journals, books, etc. Primary data is collected from financial reports of 24 PCFs in Vietnam's Mekong Delta Region in the period of 2013-2018. This research has analyzed and synthesized the theoretical basis relating to operational selfsustainability and credit growth of PCFs. Based on the synthesized and analyzed theories, the paper defines the factors affecting operational self-sustainability and credit growth, the analysis model of the interactive relationship between credit growth and operational self-sustainability of people's credit funds in Vietnam's Mekong Delta Region is established as follows:

$$
\mathrm{Y}_{1}=\alpha_{10}+\alpha_{11} \mathrm{Y}_{2}+\sum_{k=1}^{n} \beta_{1 \mathrm{k}} \mathrm{X}_{1 \mathrm{k}}+\mu_{1}
$$

$\mathrm{Y}_{2}=\alpha_{20}+\alpha_{21} \mathrm{Y}_{1}+\sum_{\gamma=1}^{m} \beta_{2 \gamma} \mathrm{X}_{2 \gamma}+\mu_{2}$

Where,

$Y_{1}$ is the variable that measures credit growth, determined by the rate of the increase in credit sizes and $Y_{2}$ is a variable that measures operational self-sustainability, determined by the ratio of operating income to total operating expenses, financing costs and provision for loan losses. $X_{1 k}$ and $X_{2 y}$ are the independent variables that can affect credit growth and operational self-sustainability in equations (1) and (2), respectively.

The coefficient $\alpha$ and coefficient $\beta$ are the correlation coefficients of the independent variables with the dependent variables, which are the error terms of the model. For simplicity, indicator i represents the number of observations and indicator $t$ represents the number observed year. The definitions of variables and expected signs are presented in Table 1. This study uses Stata 15.0 software with the variables described briefly as follows (Table 1 ): 
Table 1: Summary of the research model variables

\begin{tabular}{|c|c|c|c|c|c|c|}
\hline \multicolumn{4}{|c|}{ Variables and symbols } & & Definition & Expected sign and hypotheses \\
\hline \multicolumn{7}{|c|}{ Factors affecting credit growth } \\
\hline \multicolumn{7}{|c|}{ Dependent variable } \\
\hline \multicolumn{4}{|c|}{ Credit growth rate (CGR) } & \multicolumn{2}{|c|}{ Growth in loan outstanding } & \\
\hline \multicolumn{7}{|c|}{ Independent variables } \\
\hline \multicolumn{4}{|c|}{ Capital Adequacy Ratio (CAR) } & \multicolumn{2}{|c|}{ Total Capital / Risk Weighted Assets } & H1.1: + (high CAR, high CGR) \\
\hline \multicolumn{4}{|c|}{ Deposit growth rate (DGR) } & \multicolumn{2}{|c|}{ Growth rate of customer deposits } & H1.2: + (high DGR, high CGR) \\
\hline \multicolumn{4}{|c|}{ Equity growth rate (EGR) } & \multicolumn{2}{|c|}{ Growth rate of equity } & H1.3: + (high EGR, high CGR) \\
\hline \multicolumn{4}{|c|}{ Loan-to-deposit ratio (LDR) } & \multicolumn{2}{|c|}{ Total loans / Total deposits } & H1.4: + (high LDR, high CGR) \\
\hline \multicolumn{4}{|c|}{ Non-performing loan ratio (NPL) } & \multicolumn{2}{|c|}{ Non-performing loans / Total loans } & H1.5: - low (NPL, high CGR) \\
\hline \multicolumn{4}{|c|}{ Operational self - sustainability (OSS) } & \multicolumn{2}{|c|}{$\begin{array}{l}\text { Operating income / (Operating expenses } \\
+ \text { financing costs + provision for loan losses) }\end{array}$} & H1.6: + (high OSS, high CGR) \\
\hline \multicolumn{4}{|c|}{ Gross domestic product (GDP) } & \multicolumn{2}{|c|}{ Growth rate of gross domestic product } & H1.7: + (high GDP, high CGR) \\
\hline \multicolumn{4}{|c|}{\begin{tabular}{|l|l} 
Inflation (INF) & \\
\end{tabular}} & \multicolumn{2}{|c|}{ Change of the consumer price index annually } & H1.8: + / -(high / low GDP, high CGR) \\
\hline \multicolumn{7}{|c|}{ Factors affecting Operational self - sustainability } \\
\hline \multicolumn{7}{|c|}{\begin{tabular}{|l|l|} 
Dependent variable & \\
\end{tabular}} \\
\hline \multicolumn{4}{|c|}{ Operational self - sustainability (OSS) } & \multicolumn{2}{|c|}{$\begin{array}{l}\text { Operating income / (Operating expenses } \\
+ \text { financing costs + provision for loan losses) }\end{array}$} & \\
\hline \multicolumn{7}{|c|}{ Independent variable } \\
\hline \multicolumn{4}{|c|}{ Capital Adequacy Ratio (CAR) } & \multicolumn{2}{|c|}{ Total Capital / Risk Weighted Assets } & H2.1: + (high CAR, high OSS) \\
\hline Credit gro & th rate & CGR) & & Growth in I & oan outstanding & H2.2: + (high CGR, high OSS) \\
\hline Deposit gr & wth ra & (DGR) & & Growth rat & e of customer deposits & H2.3: + (high DGR, high OSS) \\
\hline Equity gro & th rate & EGR) & & Growth rat & e of equity & H2.4: + (high EGR, high OSS) \\
\hline Income (II & & & & Operating & income & H2.5: + (high INC, high OSS) \\
\hline Non-perfo & ning Ic & n ratio (NPL) & & Non-perfor & ming loans / Total loans & H2.6: - (Low NPL, high OSS) \\
\hline Variable & Obs & Mean & Std. Dev. & Min & & $\operatorname{Max}$ \\
\hline CGR & 144 & .0669514 & .1466846 & -.214 & & 1.087 \\
\hline CAR & 144 & 18.04 & 6.779657 & 8.02 & & 41.15 \\
\hline DGR & 144 & .0687174 & .1798071 & -.37 & & 1.022 \\
\hline EGR & 144 & 8.792431 & 16.37872 & -12.15 & & 160.42 \\
\hline LDR & 144 & 1.041451 & .1961791 & .688 & & 1.969 \\
\hline NPL & 144 & 1.201736 & 1.189866 & 0 & & 6.34 \\
\hline OSS & 144 & 114.6664 & 8.809506 & 71.38 & & 142.44 \\
\hline GDP & 144 & 6.363333 & .5607787 & 5.42 & & 7.08 \\
\hline INF & 144 & 3.508333 & 1.781145 & .63 & & 6.6 \\
\hline
\end{tabular}

Table 3: Correlation matrix for factors affecting credit growth

\begin{tabular}{|c|c|c|c|c|c|c|c|c|c|}
\hline & CGR & CAR & DGR & EGR & LDR & NPL & OSS & GDP & INF \\
\hline CGR & 1.0000 & & & & & & & & \\
\hline CAR & -0.1833 & 1.0000 & & & & & & & \\
\hline DGR & 0.5501 & -0.0822 & 1.0000 & & & & & & \\
\hline EGR & 0.2097 & 0.0067 & 0.1837 & 1.0000 & & & & & \\
\hline LDR & 0.1257 & 0.2640 & -0.1966 & -0.0028 & 1.0000 & & & & \\
\hline NPL & 0.0506 & 0.0204 & 0.0467 & 0.2475 & -0.0423 & 1.0000 & & & \\
\hline OSS & -0.1726 & 0.1935 & 0.0561 & -0.1577 & 0.0477 & -0.4122 & 1.0000 & & \\
\hline GDP & -0.1967 & 0.1185 & -0.4153 & -0.1509 & 0.1366 & -0.0028 & -0.3365 & 1.0000 & \\
\hline INF & 0.1691 & -0.0948 & 0.2693 & 0.0830 & 0.1129 & -0.0524 & 0.2788 & -0.6534 & 1.0000 \\
\hline
\end{tabular}

\section{Research Results}

\subsection{Factors Affecting Credit Growth}

\subsubsection{Descriptive Statistics and Correlation Analysis}

Descriptive statistics of both dependent and independent variables are presented in Table 2 . The results testify that CGR, CAR, LDR, NPL, OSS, GDP, INF variables have smaller standard deviations than the average. DGR and EGR variables have fluctuations, due to the large difference in equity, equity growth rate, deposits and deposit growth rate between PCFs in Mekong Delta region of Vietnam in the period from 2013 - 2018.

The analysis results of correlation between variables in the model indicate a very low degree of correlation among the variables, the presence of any multicollinearity is neglected (Table3). 


\subsubsection{Regression Results}

Regression is carried out using Fixed effects model (FEM), Random effects model (REM), and Pooled ordinary least square (OLS) model between CGR dependent variable and CAR, DGR, EGR, LDR, NPL, OSS, GDP, INF independent variables.

According to the results of FEM and REM, both P-values are less than the significance level of $5 \%(P$-value $=0.000)$, so the regression models are statistically significant at the significance level of $5 \%$. In both FEM and REM, variables OSS and CAR have negative impacts on the variable CGR at the significance level of $5 \%$ and $10 \%$; variables DGR and LDR have positive impacts on the variable CGR at the significance level of $1 \%$. Variable NPL has a negative impact on the variable CGR, and variable EGR has a positive impact on the variable CGR but these variables are not statistically significant. For variables GDP and INF, these variables have negative impacts on the variable CGR but are not statistically significant in the REM and these variables have no effect on CGR in the FEM (Table 4).

Table 4: Regression results of FEM and REM for factors affecting credit growth

\begin{tabular}{|l|c|c|}
\hline \multirow{2}{*}{$\begin{array}{c}\text { Independent } \\
\text { variables }\end{array}$} & \multicolumn{2}{|c|}{ Dependent variable (CGR) } \\
\cline { 2 - 3 } CAR & $\begin{array}{c}-0.00365^{2} \\
(-2.41)\end{array}$ & $\begin{array}{c}-0.00355^{\mathrm{a}} \\
(-2.31)\end{array}$ \\
\hline \multirow{2}{*}{ DGR } & $\begin{array}{c}0.473^{3} \\
(8.03)\end{array}$ & $\begin{array}{c}0.472^{\mathrm{b}} \\
(7.37)\end{array}$ \\
\hline \multirow{2}{*}{ EGR } & $\begin{array}{c}0.000742 \\
(1.21)\end{array}$ & $\begin{array}{c}0.000818 \\
(1.27)\end{array}$ \\
\hline LDR & $\begin{array}{c}0.225^{\mathrm{b}} \\
(4.25)\end{array}$ & $\begin{array}{c}0.222^{\mathrm{b}} \\
(4.15)\end{array}$ \\
\hline NPL & -0.00864 & -0.00960 \\
& $(-0.96)$ & $(-1.03)$ \\
\hline \multirow{2}{*}{ OSS } & $-0.00356^{4}$ & $-0.00382^{\mathrm{c}}$ \\
& $(-2.66)$ & $(-2.75)$ \\
\hline GDP & -0.0130 & 0 \\
& $(-0.52)$ & $()$. \\
\hline INF & -0.00170 & 0 \\
& $(-0.23)$ & $()$. \\
\hline cons & 0.367 & 0.309 \\
\hline P-value & 0.0000 & 0.0000 \\
\hline N & 144 & 144 \\
\hline & & \\
\hline
\end{tabular}

\footnotetext{
2 Significance at the level of $10 \%$.

${ }^{3}$ Significance at the level of $1 \%$.

${ }^{4}$ Significance at the level of $5 \%$.
}

This study performed Hausman test to select the appropriate model and Hausman test result obtains a Pvalue of 0.9978 , greater than the significance level of $5 \%$, so REM is more suitable than FEM. In comparison with OLS Pooled model, REM is more suitable than OLS Pooled model. Therefore, the study uses REM regression results in order to analyze and test next steps. The multicollinearity test of the model with Mean VIF = 1.62; VIF of variables CGR, CAR, DGR, EGR, LDT, NPL, OSS, INF are all less than 2 and VIF of variable GDP is less than $3\left(\mathrm{VIF}_{\mathrm{CGR}}=1.80\right.$, $V I F_{C A R}=1.24, V_{I F} F_{D R}=1.88, V_{I F} F_{E G R}=1.15, V_{I F}=1.38$, $\left.\mathrm{VIF}_{\mathrm{NPL}}=1.31, \mathrm{VIF}_{\mathrm{OSS}}=1.65, \mathrm{VIF}_{\mathrm{GDP}}=2.28, \mathrm{VIF}_{\mathrm{INF}}=1.92\right)$. This result shows no serious multicollinearity in this model.

Test for variance change of the model, $\mathrm{P}$-value $=1.000$ is greater than 0.05 , therefore, this model does not have variance change phenomenon. Checking the autocorrelation of the model, $\mathrm{P}$-value $=0.1708$ is greater than 0.05 so this model does not have serial correlation.

\subsection{Factors Affecting Operational Self- sustainability}

\subsubsection{Descriptive Statistics and Correlation Analysis}

Descriptive statistics of both dependent and independent variables are presented in Table 5 . The results testify that variables OSS, CAR, CGR, INC, NPL have standard deviations less than the average. Variables DGR and EGR have fluctuations, due to the large difference in equity, equity growth rate, deposits and deposit growth rate between PCFs in Mekong Delta region of Vietnam in the period from 2013 - 2018.

Table 5: Descriptive statistics for factors affecting operational selfsustainability

\begin{tabular}{|c|c|c|c|c|c|}
\hline Variable & Obs & Mean & Std. Dev. & Min & Max \\
\hline OSS & 144 & 114.6664 & 8.809506 & 71.38 & 142.44 \\
\hline CAR & 144 & 18.04 & 6.779657 & 8.02 & 41.15 \\
\hline CGR & 144 & .0669514 & .1466846 & -.214 & 1.087 \\
\hline DGR & 144 & .0687174 & .1798071 & -.37 & 1.022 \\
\hline EGR & 144 & 8.792431 & 16.37872 & -12.15 & 160.42 \\
\hline INC & 144 & 204.5032 & 239.9829 & -90.17 & 1054.21 \\
\hline NPL & 144 & 1.201736 & 1.189866 & 0 & 6.34 \\
\hline
\end{tabular}

The analysis results of correlation matrix between variables in the model indicate a very low degree of correlation among the variables, the presence of any multicollinearity is neglected (Table 6). 
Table 6: Correlation matrix for factors affecting operational selfsustainability

\begin{tabular}{|l|c|c|c|c|c|c|c|}
\hline & OSS & CAR & CGR & DGR & EGR & INC & NPL \\
\hline OSS & 1.0000 & & & & & & \\
\hline CAR & 0.1935 & 1.0000 & & & & & \\
\hline CGR & -0.1726 & -0.1833 & 1.0000 & & & & \\
\hline DGR & 0.0561 & -0.0822 & 0.5501 & 1.0000 & & & \\
\hline EGR & -0.1577 & 0.0067 & 0.2097 & 0.1837 & 1.0000 & & \\
\hline INC & 0.2646 & -0.1182 & -0.1636 & -0.0619 & 0.0166 & 1.0000 & \\
\hline NPL & -0.4122 & 0.0204 & 0.0506 & 0.0467 & 0.2475 & -0.1268 & 1.0000 \\
\hline
\end{tabular}

\subsubsection{Regression Results}

Regression in the study is carried out using Fixed effects model (FEM), Random effects model (REM), and Pooled ordinary least square (OLS) model between OSS dependent variable and CAR, CGR, DGR, EGR, INC, NPL independent variables.

According to the estimation results of FEM and REM, the values of $\mathrm{P}$-value of both models are less than the significance level of $5 \%(P$-value $=0.000)$, so the regression models are statistically significant at the significance level of $5 \%$. In both FEM and REM, variables NPL and CGR have negative impacts on the CGR variable at the significance level of $1 \%$ and $10 \%$; the variable INC has a positive impact on the variable OSS at the significance level of $5 \%$; the variable EGR has a negative impact on OSS but this variable is not statistically significant. The variable CAR has a positive impact on OSS at the significance level of $1 \%$ and $5 \%$ in the FEM and REM. The variable DGR has a positive impact on OSS at the significance level of $10 \%$ in the REM and has a positive impact on OSS but this variable is not statistically significant in the FEM (Table 7).

Table 7: Regression results of FEM and REM for factors affecting operational self-sustainability

\begin{tabular}{|c|c|c|}
\hline \multirow{2}{*}{ Independent variables } & \multicolumn{2}{|c|}{ Dependent variable (OSS) } \\
\cline { 2 - 3 } & REM & FEM \\
\hline \multirow{2}{*}{ CAR } & $0.277^{5}$ & $0.321^{6}$ \\
& $(2.91)$ & $(3.75)$ \\
\hline \multirow{2}{*}{ CGR } & $-10.97^{\prime}$ & $-10.39^{\dagger}$ \\
& $(-2.06)$ & $(-2.18)$ \\
\hline \multirow{2}{*}{ DGR } & $10.72^{\dagger}$ & 3.592 \\
& $(2.56)$ & $(0.84)$ \\
\hline \multirow{2}{*}{ EGR } & -0.0393 & -0.0328 \\
& $(-0.97)$ & $(-0.86)$ \\
\hline \multirow{2}{*}{ INC } & $0.00836^{\mathrm{d}}$ & $0.00746^{\mathrm{d}}$ \\
& $(3.09)$ & $(3.04)$ \\
\hline \multirow{2}{*}{ NPL } & $-2.744^{\mathrm{e}}$ & $-2.701^{\mathrm{e}}$ \\
& $(-5.01)$ & $(-5.42)$ \\
\hline Cons & 111.6 & 111.3 \\
\hline P-value & 0.0000 & 0.0000 \\
\hline N & 144 & 144 \\
\hline
\end{tabular}

\footnotetext{
${ }^{5}$ Significance at the level of $5 \%$.

${ }^{6}$ Significance at the level of $1 \%$.

${ }^{7}$ Significance at the level of $10 \%$.
}

This study performed Hausman test to select the appropriate model and Hausman test result obtains P-value $=0.9978$ greater than the significance level of $5 \%$, so REM is more suitable than FEM, Comparing REM with the OLS Pooled model and REM is more suitable than the OLS Pooled model. Therefore, the study uses REM regression results in order to analyze and test the next steps. Multicollinearity test of the model gives the results with Mean VIF = 1.32; VIF of all variables are less than $2\left(\mathrm{VIF}_{\mathrm{OSS}}\right.$ $=1.45, \mathrm{VIF}_{\mathrm{CAR}}=1.13, \mathrm{VIF}_{\mathrm{CGR}}=1.61, \mathrm{VIF}_{\mathrm{DGR}}=1.52, \mathrm{VIF}_{\mathrm{EGR}}$ $\left.=1.14, V_{I F} I_{N C}=1.15, V_{I F} F_{N L}=1.28\right)$. The result shows no multicollinearity phenomenon in this model.

Checking the variance change of the model, $\mathrm{P}$-value = 1.000 , greater than 0.05 so this model does not have variance change phenomenon. Checking autocorrelation of the model, P-value $=0.4756$ is greater than 0.05 so this model does not have serial correlation.

\section{Discussions}

\subsection{Discussions of the Model of Factors Affecting Credit Growth}

The results of REM (Table 4) reflect that variable CAR has a negative impact on CGR with coefficient -0.00365 and variable CAR has positive effects on CGR with the significance level of $10 \%$, indicating that CAR has an impact on CGR. This result contrasts with the expected sign and hypotheses; at the same time, this result disagrees with the analysis results of Ledgerwood (1999), Berrospide and Edge (2010), Catalán, Hoffmaister and Harun (2017), Phi, Hoang, Taghizadeh-Hesary and Yoshino (2019). Many PCFs maintain a high capital adequacy ratio of over $20 \%$ due to their limitations in loans providing ability and risk concerns in the recent period. Therefore, capital adequacy ratio had a negatively impact on credit growth of PCFs in Mekong Delta region of Vietnam in the past years.

The variable DGR has a positive impact on CGR with coefficient 0.473 and variable CGR has a positively affects on OSS with the significance level of $1 \%$, indicating that DGR has a strong impact on OSS. This result agrees with the expected sign and hypotheses; at the same time, this result agrees with the analysis results of Barajas, Chami, Espinoza, and Hesse (2010) and Tan (2012), credit institutions that have higher deposit growth tend to expand credit more rapidly and the deposit expansion contributes positively to credit growth of credit institutions. PCFs are institutions that provide loans mainly from mobilized capital, so in the past few years, PCFs have always increased capital mobilization to meet the needs of credit growth. 
Therefore, high rate of deposit growth promotes credit growth of PCFs in the Mekong Delta region of Vietnam.

The variable LDR has a positive impact on CGR with a coefficient of 0.225 and variable LDR has a positive effect on OSS with the significance level of $1 \%$, indicating that LDR has a strong impact on OSS. This result agrees with the expected sign and hypotheses; at the same time, this result agrees with the analysis results of Barkley, Mellon, and Potts (1984), DiSalvo and Johnston (2017), loan to deposit ratio of large credit institutions reaches high value as their lending expands rapidly. In the past period, the loan-to-deposit ratio of PCFs reached a high value as their lending expanded rapidly. Therefore, a high rate of the loanto-deposit ratio promotes credit growth of PCFs in the Mekong Delta region of Vietnam.

The variable OSS has a negative impact on CGR with a coefficient of -0.00356 and variable OSS has a positive effect on CGR with the significance level of $5 \%$, indicating that CAR has a strong impact on CGR. This result contrasts with the expected sign and hypotheses; at the same time, this result does not agree with the analysis results of Lyons (2012). The PCFs always aim at operational selfsustainability, at the same time, they ensure credit growth. However, to ensure operational self-sustainability, PCFs need to ensure their income and reduce costs, while the extra income is not commensurate with the rising costs over the years. Therefore, there is a trade-off between credit growth and operational self-sustainability of PCFs in the Mekong Delta region of Vietnam.

These research results are accurate according to the characteristics of PCFs and the development history of PCFs in the Mekong Delta region of Vietnam from 20132018. On one hand, PCFs improve deposit mobilization to promote credit growth and to improve loan-to-deposits ratio step by step, etc. On the other hand, this study does not find a statistically significant impact between EGR, NPL, GDP and INF variables on CGR variable. This is consistent with the fact that PCFs mainly used external mobilized funds to provide financial services and loans under the conditions of low equity in these years. In particular, credit growth was low and non-performing loan ratio was concerned by many PCFs and most of PCFs had low non-performing loan ratio.

\subsection{Discussions of the Model of Factors Affecting Operational Self-sustainability}

The results of REM (Table 7) reflect that variable CAR has a positive influence on OSS with a coefficient of 0.277 and variable CAR has positive effects on OSS with the significance level of $5 \%$, indicating that CAR has a strong impact on OSS. This result agrees with the expected sign and hypotheses; at the same time, this result agrees with the analysis results of Ledgerwood (1999), sufficient capital is one of the key factors affecting the healthiness and sustainability of credit institutions. In recent years, the PCFs in the Mekong Delta region of Vietnam have always maintained a capital adequacy ratio of over $8 \%$ to meet the requirements of the operational development. Therefore, a high capital adequacy ratio will contribute positively to improving the self-sustainability of PCFs in the Mekong Delta region of Vietnam.

The variable INC has a positive impact on OSS with a coefficient of 0.00836 and variable INC has a positive effect on OSS with the significance level of $5 \%$, indicating that INC has a strong impact on OSS. This result agrees with the expected sign and hypotheses; at the same time, this result agrees with the analysis results of Yaron (1992), Amit and Kedar (2014). There are 23 out of 24 PCFs that ensure operating income annually. This is a favorable condition that promoted the stable activities of PCFs developed in the recent period. Therefore, income is one of the factors promoting high operational self-sustainability of PCFs in the Mekong Delta region of Vietnam.

The variable DGR has a positive impact on OSS with a coefficient of 10.72 and variable DGR has a positive effect on OSS with the significance level of $10 \%$, indicating that DGR has an impact on OSS. This result agrees with the expected sign and hypotheses; at the same time, this result agrees with the analysis results of Brau and Woller (2004), CGAP (2005) and UNESCAP (2006), deposit growth improves the sustainability of the credit institutions. PCFs are institutions that provide loans mainly from the mobilized capital, so in the past few years, PCFs have always increased capital mobilization to meet the needs of expanding their operations. Therefore, a high rate of deposit growth promotes high operational self-sustainability of PCFs in the Mekong Delta region of Vietnam.

The variable CGR has a negative impact on OSS with a coefficient of -10.97 and CGR variable has a negative effect on OSS with the significance level of $10 \%$, indicating that CGR has a significant influence on OSS. This result contrasts with the expected sign and hypotheses; at the same time, this result disagrees with the analysis results of Painter and MkNelly (1999), Weber (2013), Tehulu (2013). There is a contradictory relationship between credit growth and operational self-sustainability. PCFs increase credit size to create income, but the extra income is not commensurate with the increasing expenses in the past years. There is a trade-off between credit growth and operational selfsustainability of PCFs in the Mekong Delta region of Vietnam.

The variable NPL has a negative impact on OSS with a coefficient of -2.744 and the NPL variable has a negative effect on OSS with the significance level of $1 \%$, indicating 
that NPL has a strong impact on OSS. This result agrees with the expected sign and hypotheses; at the same time, this result agrees with the analysis results of Khandker, Khalily, and Khan (1995), Meyer (2002), the financial unsustainability in financial institutions arises due to low repayment rate. Most of PCFs have a low non-perfoming loan rate, which helps PCFs to ensure their operations were safety in the past years. Therefore, the increase in nonperforming loan ratio will be the risk in operational selfsustainability of PCFs in the Mekong Delta region of Vietnam.

The results of this research are accurate according to the characteristics of PCFs and the development process of PCFs in the Mekong Delta region of Vietnam from 20132018. Every year, most of PCFs step by step improve capital adequacy ratio by supplementing charter capital and increasing income during operation. PCFs improve the mobilization deposit, non-performing loan ratio is concerned by many PCFs and most of PCFs have low non-performing loan ratio. On the other hand, this study does not find a statistically significant impact between variables EGR and OSS. This is consistent with the fact that PCFs mainly use the external mobilized funds to provide financial services and loans under the conditions of low equity in the past years.

\section{Conclusions}

The objective of this paper is studying the interactive relationship between credit growth and operational selfsustainability of PCFs in the Mekong Delta region of Vietnam. Multiple regression analysis is used in this study to find out the potential factors that lead to credit growth of PCFs. Based on prior researches, eight prominent factors are identified. The results of the study show four factors, including capital adequacy ratio, deposit growth, loan-todeposit ratio and operational self-sustainability significantly influence credit growth of PCFs. The equity growth, nonperforming loan, economic growth and inflation have insignificant relationships with credit growth of PCFs. Two factors that have positive relationships with credit growth of PCFs are deposit growth and loan-to-deposit ratio. The capital adequacy ratio and operational self-sustainability have negative relationships with credit growth of PCFs. On the other hand, the factors that have the highest impact are deposit growth and loan-to-deposit ratio and it contributes to credit growth of PCFs in the Mekong Delta region of Vietnam.

At the same time, multiple regression analysis is used in this study to find out potential factors that lead to the operational self-sustainability of PCFs. Based on prior researches, six prominent factors were identified. The results of the study show five factors, including capital adequacy ratio, credit growth, deposit growth, income and loan-to-deposit ratio significantly influence the operational self-sustainability of PCFs. Equity growth has an insignificant relationship with the operational selfsustainability of PCFs. Three factors that have positive relations with the operational self-sustainability of PCFs are capital adequacy ratio, deposit growth and income. Credit growth and non-performing loan ratio have negative relationships with the operational self-sustainability of PCFs. On the other hand, factor that has the highest impact on operational self-sustainability is non-performing loan ratio, and the control of non-performing loans has contributed to the operational self-sustainability of PCFs in the Mekong Delta region of Vietnam.

The multiple regression analysis results of two models for factors affecting credit growth and factors affecting operational self-sustainability of PCFs in the Mekong Delta region of Vietnam, this study can conclude that two dependence variables of the two models are statistically significant and there is interaction between credit growth and operational self-sustainability of PCFs in the Mekong Delta region of Vietnam.

The Mekong Delta of Vietnam is a developing region, PCFs are recognized organizations that alleviate poverty have been operating to help the poor of the country. Nowadays, PCFs are having significant investment prospects in many regions of the country. This study helps researchers, managers to develop their expertise in the key determinants of credit growth, operational self-sustainability and the interaction between credit growth and operational self-sustainability of PCFs. At the same time, base on the research results, the article recommends key content to improve operational self-sustainability and credit growth of PCFs in the Mekong Delta region of Vietnam as follows.

Firstly, PCFs are credit institutions that are allowed to mobilize deposit to lend to its members. Therefore, to ensure operation self-sustainability, PCFs must follow the general principle of ensuring safety for banking operations.

Secondly, strengthening financial capacity by increasing charter capital, attracting new members. PCFs focus on lending to its members and the poor for credit growth, therefore, strict control over credit growth quality and efficiency is necessary to ensure operational selfsustainability of PCFs.

Thirdly, the operations of PCFs ensure to comply with the cooperative principles in order to enhance mutual support and cooperation among members, focus on the main purpose of mutual assistance in production, business development, the life of its members and serving communities in the area. 
Fourthly, PCFs need to balance sufficient resources to ensure their operational objectives. At the same time, strengthen solutions to limit the trade-off between credit growth and operational self-sustainable of PCFs.

This study assesses the interaction between credit growth and operational self-sustainability of PCFs in the Mekong Delta region of Vietnam. Subsequent researches can be extended to PCFs in Vietnam to investigate further other factors including macro and micro factors to achieve more comprehensive results on the interaction between credit growth and operational self-sustainability of PCFs.

\section{References}

Alihodžić, A., \& Ekşi, I. H. (2018). Credit growth and nonperforming loans: evidence from Turkey and some Balkan countries. Eastern Journal of European Studies, 9(2), 229-249.

Alnahedh, S., \& Bhagat, S. (2017). Impact of Bank Equity Capital on Bank Cost of Capital, (pp.3-4). University of Colorado Boulder, Leeds School of Business. Retrieved July 3, 2019 from http://leeds-faculty.colorado.edu/ bhagat/Bank-Capital-Lending.pdf

Amit, R., \& Kedar, B. (2014). An Analysis of Sustainability of Microfinance Institutions and its Determinants: Using Institutionalists Approach. Ganpat University - Faculty of Management Studies Journal of Management and Research, 8, 34-54.

Bakker, B. B., \& Gulde, A. M. (2010). The credit boom in the EU new member states: Bad luck or bad policies (IMF working paper). Washington, DC: International Monetary Fund.

Barajas, A., Chami, R., Espinoza, R., \& Hesse, H. (2010). Recent Credit Stagnation in the MENA Region: What to Expect? What Can Be Done? (IMF Working Paper, WP/10/219). Washington, DC: International Monetary Fund.

Barkley, D. L., Mellon, C., \& Potts, G. T. (1984). Effects of Banking Structure on the Allocation of Credit to Nonmetropolitan Communities. Western Journal of Agricultural Economics, 9(2), 283-292.

Berrospide, J. M., \& Edge, R. M. (2010). The Effects of Bank Capital on Lending: What Do We Know, and What Does It Mean? International Journal of Central Banking, 6(4), 5-54.

Brau, J.C., \& Woller, G.M (2004), Microfinance: A comprehensive review of the existing literature. Journal of Entrepreneurial Finance and Business Ventures, 9(1), 126.
Catalán, M., Hoffmaister, A. W., \& Harun, C. A. (2017). Bank Capital and Lending: An Extended Framework and Evidence of Nonlinearity (IMF Working Paper, WP/17/ 252). Washington, DC: International Monetary Fund.

CGAP (2005), Microfinance Consensus Guidelines: Developing Deposit Services for the Poor (p.2). Washington, DC: The World Bank Group.

Conning, J. (1999). Outreach, sustainability and leverage in monitored and peer-monitored lending. Journal of Development Economics, 60, 51-77.

Delija, A., \& Qirici, S. (2015). Financial sustainability of MFI's - Key factor for the growth and development of SME's in Albania. International Journal of Social Sciences and Education Research, 1(1), 143-155.

DiSalvo, J., \& Johnston, R. (2017). Banking Trends: The Rise in Loan-to-Deposit Ratios: Is 80 the New 60? (pp.1823). Philadelphia, PA: Federal Reserve Bank of Philadelphia, Research Department.

Growe, G., DeBruine, M., Lee, J. Y., \& Maldonado, J. F. T. (2014). The Profitability and Performance Measurement of U.S. Regional Banks Using the Predictive Focus of the "Fundamental Analysis Research". Advances in Management Accounting, 24, 189-237.

Guo, K., \& Stepanyan, V. (2011). Determinants of Bank Credit in Emerging Market Economies (IMF Working Paper, WP/11/51). Washington, DC: International Monetary Fund.

Harelimana, J. B. (2017). The Determinants of Financial and Operational Sustainability of Microfinance Institutions: Case Study of Clecam-Ejoheza Ltd. Global Journal of Management and Business Research: C Finance, 4(17).

Khandker, S. R., Khalily, B., \& Khan, Z. (1995). Grameen Bank: Performance and Sustainability (World Bank Discussion Paper No.306).

Ledgerwood, J. (1999). Microfinance Handbook - A Financial Market System Perspective (pp.216-224). Washington, D.C: The World Bank.

Lyons, T. S. (2012). Social Entrepreneurship: How Businesses Can Transform Society. In C. Whiting, E. Pillis, \& K. Townsen (Eds.), Search of the Eclusive Impact: Difficulty of Maximizing Identifying, and Measuring the Impact of Social Enterprises (pp.60-73). Santa Barbara, CA: ABC-CLIO.

Meyer, R. L. (2002). Track Record of Financial Institutions in Assisting the Poor in Asia. ADB Institute Research Paper, 49, 4-6.

MkNelly, B., \& Stack, K. (1998). Loan-size growth and sustainability in village banking programs. Small Enterprise Development, 9(2), 4-16.

Painter, J., \& MkNelly, B. (1999). Village Banking Dynamics Study: Evidence from Seven Programs. Journal of Microfinance, 1(1), 91-116. 
Oliver, A. M., Ruano, S., \& Fumás, V. S. (2012). Effect of equity capital on the interest rate and the demand for credit (Working Papers, Documentos de Trabajo, 1218). Madrid, Spain: Banco de España.

Phi, N. T. M., Hoang, H. T. H., Taghizadeh-Hesary, F., \& Yoshino, N. (2019). The Basel Capital Requirement, Lending Interest Rate, and Aggregate Economic Growth: An Empirical Study of Viet Nam (ADBI Working Paper 916). Tokyo, Japan: Asian Development Bank Institute.

Rabab'ah, M. (2015). Factors Affecting the Bank Credit: An Empirical Study on the Jordanian Commercial Banks. International Journal of Economics and Finance, 7(5), 166-178.

Tan, T. B. P. (2012). Determinants of Credit Growth and Interest Margins in the Philippines and Asia (IMF Working Paper, WP/12/123). Washington, DC: International Monetary Fund.

Tehulu, T. A. (2013). Determinants of Financial Sustainability of Microfinance Institutions in East Africa. European Journal of Business and Management, 17(5), 152-158.
The National Assembly (2010, June 16). Law on credit institutions. Retrieved July 15, 2019 from https://www.economica.vn/Portals/0/Documents/f6c24d10 3517f2a8c3ea307d119a2e0e.pdf

UNESCAP (2006). Microfinance for Poverty Reduction: Building Inclusive Financial Sectors in Asia and the Pacific (Development Papers No. 27). Bangkok, Thailand: Economic and Social Commission for Asia and the Pacific. Wachukwu, I. P., Onyema, J.I., \& Amadi, S.N. (2018). Microfinance banking and economic growth of Nigeria. $J$ Fin Mark 2018, 2(4), 16-20.

Weber, O. (2013). Impact Measurement in Microfinance: Is the measurement of the Social Return on Investment an Innovation in Microfinance? Journal of Innovation Economics \& Management, 1(11), 149-171.

Yaron, J. (1992). Assessing development finance institutions: a public interest analysis (World Bank Discussion Paper No. 174). Washington, DC: The World Bank. 